\title{
Boraxs and Formalin Analysis in the Shumai Treated in Palu City
}

\section{${ }^{*}$ Areeya Milehman \& Mery Napitupulu}

Pendidikan Kimia/FKIP - Universitas Tadulako, Palu - Indonesia 94119

Received 23 March 2020, Revised 27 April 2020, Accepted 29 May 2020

doi: 10.22487/j24775185.2020.v9.i2.pp118-124

\section{Abstract}

This study aims to test and prove the presence of borax and formalin contamination in shumai samples sold in Palu City. Qualitative method with curcumin paper test; and quantitatively using the $U V$-Vis spectrophotometer method on a $550 \mathrm{~nm}$ waveform, so that the borax content can be determined in the sample. From the results of this study as many as 5 shumai samples examined, all samples from 5 samples tested qualitatively positive were found before the quantitative analysis was carried out before the samples were tested qualitatively. Qualitative tests showed that some samples did not contain formaldehyde but positively contained borax so the quantitative test was only conducted to determine borax levels in shumai. The results stated that the lowest level was $0.0213 \mathrm{mg} / \mathrm{g}$ and the highest level was $0.0314 \mathrm{mg} / \mathrm{g}$.

Keywords: Boraxs, formalin, shumai

\section{Pendahuluan}

Bahan tambahan pangan yang disingkat BTP adalah bahan yang ditambahkan ke dalam pangan untuk mempengaruhi sifat atau bentuk pangan. BTP tidak dimaksudkan untuk dikonsumsi secara langsung dan/atau tidak diperlakukan sebagai bahan baku pangan. BTP dapat mempunyai atau tidak mempunyai nilai gizi, yang sengaja ditambahkan ke dalam pangan untuk tujuan teknologis pada pembuatan, pengolahan, perlakuan, pengepakan, pengemasan, penyimpanan dan/atau pengangkutan pangan untuk menghasilkan atau diharapkan menghasilkan suatu komponen atau mempengaruhi sifat pangan tersebut, baik secara langsung atau tidak langsung. Bahan ini berfungsi untuk memperbaiki warna, bentuk, cita rasa, dan tekstur, serta memperpanjang masa simpan, dan bukan merupakan bahan (ingredient) utama serta tidak termasuk cemaran atau bahan yang ditambahkan ke dalam pangan untuk mempertahankan atau meningkatkan nilai gizi.

Penggunaan bahan tambahan dilarang jika bertujuan untuk menutupi mutu yang rendah serta menyembunyikan cara pengolahan yang tidak baik (Purwanti, 2003). Meningkatnya pertumbuhan industri makanan di Indonesia, telah terjadi peningkatan produksi makanan yang beredar di masyarakat. Sudah tidak asing lagi bahwa banyak zat-zat berbahaya yang langsung dicampur sebagai bahan tambahan makanan, beberapa zat yang sering digunakan yaitu boraks dan formalin. Boraks termasuk bahan yang berbahaya dan beracun sehingga tidak boleh digunakan sebagai BTP. Boraks sendiri memiliki efek karsinogenik yang menyebabkan gangguan otak, hati, dan ginjal serta berbahaya bagi susunan saraf pusat. Oleh sebab itu, boraks dilarang penggunaannya oleh pemerintah dan dimasukkan dalam golongan senyawa yang disebut bahan berbahaya dan beracun (B3) (Alsuhendra \& Ridawati, 2013).

Formalin digolongkan sebagai bahan tambahan pangan yang tidak izinkan di Indonesia. Formalin dilarang penggunaanya karena banyak menimbulkan penyakit bagi kesehatan. Formalin akan menyebabkan iritasi dan rasa terbakar pada mukosa kavum nasi, mulut dan saluran nafas bagian atas jika masuk secara inhalasi (Nash, 1999). Pada konsentrasi lebih tinggi mampu mencapai bronkiolus dan alveoli lalu menginduksi edema paru dan pneumonia. Sedangkan bila tertelan dalam konsentrasi tinggi menimbulkan gejala akut berupa iritasi di mulut, kerongkongan, ulkus di saluran pencernaan, nyeri dada dan perut, mual, muntah, diare, perdarahan gastrointestinal, asidosis metabolik, gagal ginjal bahkan kematian (Suntaka, 2014).

Boraks dan formalin meskipun bukan pengawet makanan, sering pula digunakan sebagai pengawet makanan. Boraks dan formalin sering salah digunakan untuk mengawetkan berbagai makanan seperti bakso, mie basah,

*Correspondence:

Areeya Milehman

e-mail: areeyami1995@gmail.com

(C) 2020 the Author(s) retain the copyright of this article. This article is published under the terms of the Creative Commons Attribution License 4.0, which permits unrestricted non-commercial use, distribution, and reproduction in any medium, provided the original work is properly cited. 
pisang molen, siomay, lontong, ketupat, pangsit, $\mathrm{dsb}$. Selain bertujuan untuk mengawetkan, boraks dan formalin juga dapat membuat tekstur makanan menjadi lebih kenyal dan memperbaiki penampilan makanan, utuh, tidak rusak, menekan biaya produksi, praktis dan efektif mengawetkan makanan (Habibah, 2013.).

Kota Palu dipilih sebagai lokasi pengambilan sampel dengan alasan selain domisili peneliti berada di kota Palu juga siomay menjadi salah satu jajanan favorit di kota ini. Beberapa siomay yang terkenal di kota Palu seperti Raja siomay Mas Fais, Siomay 88, Siomay Mas Muji dan masih banyak lagi. Karena siomay menjadi jajanan favorit, maka perlu dilakukan analisis kesehatan terhadap jajaan tersebut untuk menghindari hal-hal yang tidak diinginkan.

Tulisan ini bertujuan untuk menguraikan analisis kandungan boraks dan formalin pada siomay yang dijajakan di Kota Palu.

\section{Metode}

\section{Preparasi dan Ekstraksi Sampel}

Alat-alat yang digunakan dalam penelitian ini adalah pipet tetes, gelas kimia, batang pengaduk, Erlenmeyer, alluminium foil, kain kasa, corong, neraca digital, kuvet, rak tabung reaksi, waterbath/wadah, blender, penangas listrik, lumpang dan alu, sepatula, pisau, oven, dan spektrofotometri UV-VIS. Adapun bahan yang digunakan dalam penelitian ini adalah Sampel siomay, padatan $\mathrm{CaCO}_{3}$, larutan $\mathrm{HCl}$ $10 \%$, kertas saring, kertas label, kunyit, aquades dan tissue.

\section{Uji Kualitatif Boraks dan Formalin a) Pengujian Boraks Uji Warna Kertas Kurkumin}

Sampel dicincang hingga halus kemudian diovenkan selama 30 menit dengan suhu $70^{\circ} \mathrm{C}$ setelah itu $5 \mathrm{~g}$ sampel dimasukkan ke dalam cawan lanur dan tambahkan 5 g padatan $\mathrm{CaCO}_{3}$ kemudian campuran tersebut ditanur dengan suhu $600^{\circ} \mathrm{C}$ selama 5 jam dan ditambahkan $3 \mathrm{~mL} \mathrm{HCl}$ $10 \%$ ke dalam sisa pemijaran, kemudian mencelupkan kertas kurkumim (Tumbel, 2010).

\section{b) Pengujian Formalin \\ Uji dengan Larutan $\mathrm{KMnO} 0.1 \mathrm{~N}$}

$10 \mathrm{~g}$ sampel dicincang hingga halus. dengan menambahkan aquades panas $20 \mathrm{~mL}$ lalu diaduk dan disaring dan filtrat dimasukkan ke dalam tabung reaksi. Setelah itu ditambahkan 5 tetes larutan $\mathrm{KMnO} 40.1 \mathrm{~N}$ dengan menggocokkan tabung reaksi dan amati perubahan yang terjadi.

\section{Uji Kuantitatif Boraks dan Formalin \\ a) Penetapan Kadar Boraks}

$2.5 \mathrm{mg}$ boraks dilarutkan ke dalam 100 $\mathrm{mL}$ aquades. 5 gram sampel yang telah di oven kemudian diabukan pada suhu $600^{\circ} \mathrm{C}$ selama 5 jam. $20 \mathrm{~mL}$ aquades panas ditambahkan ke dalam sampel abu kemudian diaduk dengan batang pengaduk. Selanjutnya disaring dan dimasukan ke dalam labu ukur dan ditambahkan aqudes hingga tanda batas. Kemudian diukur dengan mengatur spektro pada rentang panjang gelombang $550 \mathrm{~nm}$ dengan malakukan pengukuran untuk larutan baku $100 ; 150 ; 200 ; 250 ; 500$ ppm dan setiap harga serapan untuk tiap larutan dan dibuat kurva standar antara konsentrasi (ppm) dan absorbansi (A) (Tumbel, 2010).

\section{b) Penetapan Kadar Formalin}

Larutan induk formaldehid $37 \%$ (formalin) diencerkan menjadi $0 ; 1.0 ; 1.5 ; 2.0$; 2.5, dan $3.0 \mathrm{ppm}$. Kemudian dimasukkan ke dalam tabung reaksi masing-masing $5 \mathrm{~mL}$ larutan. Kemudian di tambahkan $5 \mathrm{~mL}$ asam kromatofat $0,5 \%$ dalam asam sulfat $60 \%$ dan dipanaskan larutan selama 15 menit pada suhu $100^{\circ} \mathrm{C}$ dan diukur serapannya menggunakan Spektrofotometri UV-Vis pada panjang gelombang $520 \mathrm{~nm}$. Setelah itu dibuat kurva kosentrasi larutan standar vs absorbansinya.

10 gram sampel dimasukkan ke dalam gelas kimia dan ditambahkan $100 \mathrm{~mL}$ aquades lalu dilakukan penyaringan dan dimasukkan $5 \mathrm{~mL}$ filtrat dan $5 \mathrm{~mL}$ asam kromatofat $0.5 \%$ dalam asam sulfat $60 \%$. Kemudian dipanaskan selama 15 menit pada suhu $100^{\circ} \mathrm{C}$. Kemudian didinginkan sampel lalu mengukur serapannya menggunakan Spektrofotometri UV-Vis pada panjang gelombang $520 \mathrm{~nm}$ dengan dibuat kurva konsentrasi larutan sampel vs absorbansinya (Hariyadi, 2013).

\section{Hasil dan Pembahasan \\ Data Hasil Uji Kualitatif Boraks dan Formalin Data Hasil Pengujian Boraks}

Hasil pengujian kualitatif boraks dengan kertas kurkumin diperlihatkan pada Gambar 1 dan disajikan pada Tabel 1.

\section{Data Hasil Pengujian Formalin}

Hasil pengujian formalin dengan larutan $\mathrm{KMnO}_{4} 0.1 \mathrm{~N}$ pada larutan sampel diperlihatkan pada Gambar 2 dan disajikan pada Tabel 2.

Sampel negatif mengandung boraks. Hasil ini juga didukung pengujian yang dilakukan oleh Efrilia (2016). 


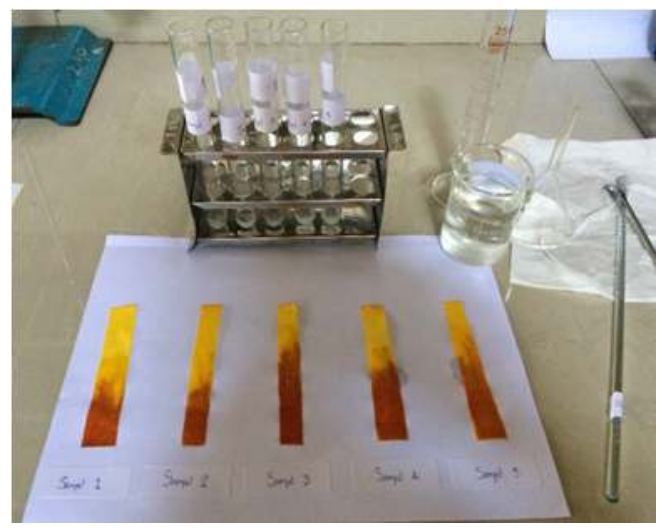

Gambar 1. Uji kualitatif boraks dengan kertas kurkumin

Tabel 1. Hasil pengujian kualitatif boraks dengan kertas kurkumin

\begin{tabular}{cccc}
\hline Sampel & Pereaksi & Uji warna & Hasil \\
\hline Sampel 1 & HCl 10\% & Coklat kemerahan & Positif $(+)$ \\
Sampel 2 & HCl 10\% & Coklat kemerahan & Positif $(+)$ \\
Sampel 3 & HCl 10\% & Coklat kemerahan & Positif $(+)$ \\
Sampel 4 & HCl 10\% & Coklat kemerahan & Positif $(+)$ \\
Sampel 5 & HCl 10\% & Coklat kemerahan & Positif $(+)$ \\
\hline
\end{tabular}

Keterangan: $+=$ positif mengandung formalin

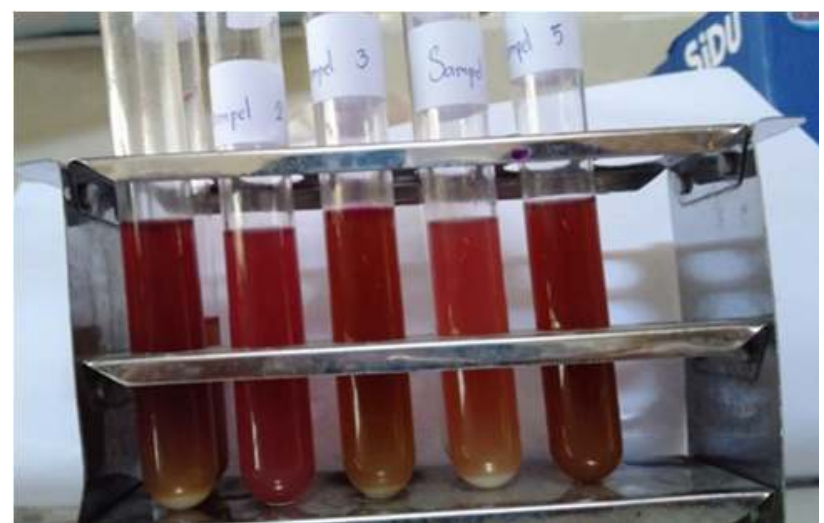

Gambar 2. Uji kualitatif formalin dengan larutan $\mathrm{KMnO}_{4} 0.1 \mathrm{~N}$.

Tabel 2. Hasil pengujian formalin dengan larutan $\mathrm{KMnO}_{4} 0,1 \mathrm{~N}$

\begin{tabular}{cccc}
\hline Sampel & Pereaksi & Uji warna & Hasil \\
\hline 1 & Larutan $\mathrm{KMnO}_{4} 0.1 \mathrm{~N}$ & Tidak hilang warna ungu & Negatif (-) \\
2 & Larutan $\mathrm{KMnO}_{4} 0.1 \mathrm{~N}$ & Tidak hilang warna ungu & Negatif (-) \\
3 & Larutan $\mathrm{KMnO}_{4} 0.1 \mathrm{~N}$ & Tidak hilang warna ungu & Negatif (-) \\
4 & Larutan $\mathrm{KMnO}_{4} 0.1 \mathrm{~N}$ & Tidak hilang warna ungu & Negatif(-) \\
5 & Larutan $\mathrm{KMnO}_{4} 0.1 \mathrm{~N}$ & Tidak hilang warna ungu & Negatif (-) \\
\hline
\end{tabular}

\section{Data Hasil Uji Kuantitatif Boraks}

\section{Analisis Kadar Boraks dalam Lerutan Standar}

Analisis kadar Boraks dalam larutan standar disajikan dalam Tabel 3.

\section{Kurva Kalibrasi Boraks}

Kurva Kalibrasi Boraks yang diperoleh dari pengukuran absorbansi larutan standar logam tersebut. Dari pengukuran kurva kalibrasi, diperoleh persamaan garis regresi, yaitu $\mathrm{Y}=$ $0.0006 \mathrm{x}+0.2868$. Data hasil pengukuran absorbansi larutan standar boraks dapat dipilih pada Tabel 3. Kurva kalibrasi larutan standar dapat dipilih pada Gambar 3. 
Tabel 3. Data analisis boraks pada larutan Standar

\begin{tabular}{ccc}
\hline No. & Konsentrasi $(\mathrm{ppm})$ & Absorbansi \\
\hline 1 & 100 & 0.305 \\
2 & 150 & 0.351 \\
3 & 200 & 0.420 \\
4 & 250 & 0.486 \\
5 & 500 & 0.539 \\
\hline
\end{tabular}

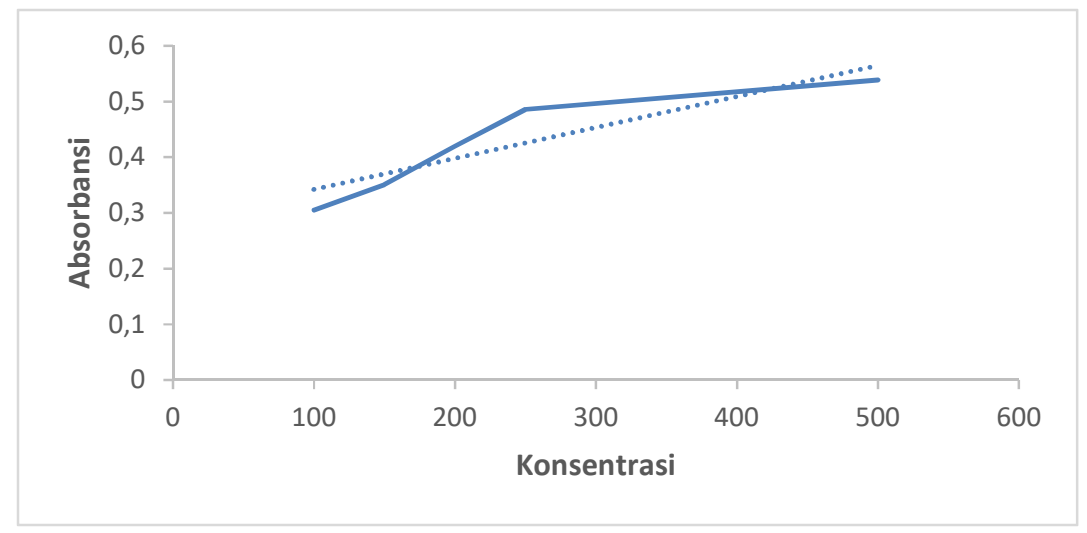

Gambar 3. Kurva kalibrasi larutan standar (boraks)

Analisis Konsentrasi Kadar Boraks dalam Sampel Siomay

Analisis konsentrasi kadar boraks dalam sampel siomay disajikan dalam Tabel 4 dan Gambar 4.

Pada penelitian ini sampel siomay diperoleh dari daerah Kota Palu yang berlokasi didepan kampus Universitas Tadulako. Lokasi tersebut dipilih karena marupakan tempat sebagai lokasi pengambilan sampel dengan alasan selain domisili peneliti berada di kota Palu juga siomay menjadi salah satu jajanan favorit di kota ini. Metode pengambilan sampel yaitu metode purposive sampel, dimana pemilihan sampel dilakukan secara random. Pengambilan sampel dilakukan hanya atas dasar pertimbangan penelitian saja yang unsur-unsur yang dikehendaki ada dalam anggota sampel yang diambil.

Tabel 4. Data konsentrasi kadar boraks dalam sampel siomay dengan alat spektrofotomater UV-Vis

\begin{tabular}{ccccl}
\hline Sampel & Perlakuan I & Perlakuan II & Perlakuan III & Rata-rata \\
\hline 1 & 0.353 & 0.354 & 0.353 & 0.353 \\
2 & 0.367 & 0.367 & 0.367 & 0.367 \\
3 & 0.451 & 0.452 & 0.451 & 0.451 \\
4 & 0.423 & 0.421 & 0.421 & 0.422 \\
5 & 0.306 & 0.307 & 0.306 & 0.306 \\
\hline
\end{tabular}

\section{Uji Kualitatif}

Identifikasi boraks dan formalin dalam supernatan dilakukan secara kualitatif untuk uji boraks dengan menggunakan uji kertas kurumin dan untuk uji formalin uji dengan menggunakan larutan $\mathrm{KMnO}_{4} 0.1 \mathrm{~N}$; dan secara kuantitatif menggunakan Spektrofotometer UV-Vis (Faradila, 2014).

Hasil penelitian menunjukkan bahwa kertas kurkumin dapat mendeteksi adanya boraks pada sampel siomay yang diuji coba. Warna jingga atau warna coklat-kemerahan yang 
dihasilkan pada kertas dan dapat dibedakan dengan kertas kurmin blanko yang berwarna kuning. Kertas kurkumin blanko berwarna kuning yang berasal dari kunyit digunakan sebagai kontrol negatif sedangkan kertas kurkumin yang berwarna merah-kecoklatan sebagai kontrol positif identifikasi adanya boraks diperoleh yaitu semua sampel dari 5 sampel mengandung boraks yang teridentifikasi adanya boraks dengan menggunakan uji kertas kurkumin. Boraks memiliki efek racun yang sangat berbahaya pada sistem metabolisme manusia sebagaimana halnya zat-zat tambahan makanan lain yang merusak kesehatan manusia. Boraks dinyatakan sebagai bahan berbahaya dan dilarang untuk digunakan dalam pembuatan makanan. Sedangkan menurut standar internasional dosis fatal boraks berkisar 3$6 \mathrm{~g} /$ hari untuk bayi dan anak kecil, untuk orang dewasa sebanyak 15-20 g/hari (Litovitz, dkk., 1998 dalam WHO, 1998). Dalam makanan boraks akan terserap oleh darah dan disimpan dalam hati. Karena tidak mudah larut dalam air boraks bersifat kumulatif selain itu boraks juga dapat menyebabkan gangguan pada bayi, gangguan proses reproduksi, menimbulkan iritasi pada lambung dan menyebabkan gangguan pada ginjal, hati, dan testes (Saputrayadi, dkk., 2018).

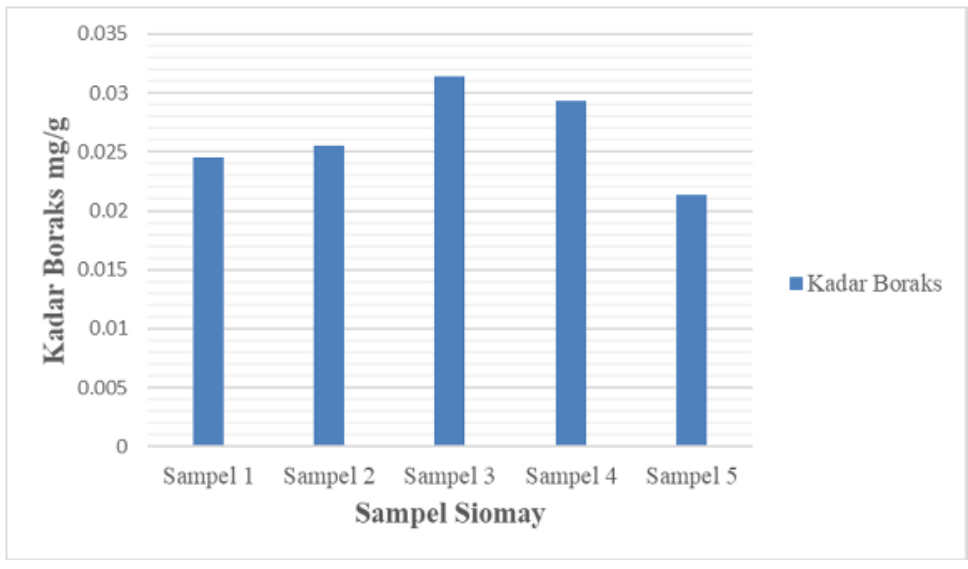

Gamber 4. Kadar boraks pada sampel yang diperoleh

Sedangkan pada uji formalin, tidak satu pun sampel yang terbukti mengandung formalin. Hal ini dilihat dari tidak adanya perubahan warna yang terjadi pada sampel jajanan yang diuji. Identifikasi formalin pada siomay dalam penelitian ini dilakukan pada siomay yang dijual di lingkungan Kota Palu. Sampel yang di ambil di 5 penjual yang berbeda, masing-masing sampel yang sudah di beli di potong kecil lalu di lakukan penimbangan sebanyak 10 gram, kemudian dioven dan di tambahkan aquadest kurang lebih $20 \mathrm{~mL}$.

Uji identifikasi formalin terhadap siomay di lakukan dengan metode reaksi warna menggunakan larutan $\mathrm{KMnO}_{4} \quad 0.1 \quad \mathrm{~N}$ proses identifikasi dengan reaksi warna di lakukan dengan cara mereaksikan 5 tetes larutan $\mathrm{KMnO}_{4}$ $0.1 \mathrm{~N}$ dengan hasil sampel telah disaring kemudian dikocok (Lidya, 2014). Amati hasil perubahan warna yang terjadi, apabila larutan yang di uji berwarna ungu pekat atau ungu terang berarti sampel tersebut di nyatakan terdeteksi mengandung formalin. Menurut Sahara \& Purawisastra (2011) berbagai jenis makanan mempunyai tingkat penyerapan formalin yang berbeda-beda seperti dalam penelitiannya daging paha ayam.

\section{Uji Kuantitatif}

Hasil penelitian ini menunjukkan bahwa semua sampel dari 5 sampel yang diuji boraks secara kualitatif positif mengandung boraks dengan kadar yang berbeda-beda pada uji kuantitatif. Langkah pertama pada penelitian ini adalah penentuan panjang gelombang maksimum pada larutan yang sudah dipreparasi. Panjang maksimum yang dilakukan pada penelitian ini adalah $550 \mathrm{~nm}$. Preparasi larutan boraks direaksikan dengan kurkumin karena larutan boraks marupakan larutan yang tidak berwarna dan tidak memiliki gugus kromotor oleh asam kuat, boraks terurai dari ikata-ikatannya menjadi asam borat dan diikat oleh kurkumin membentuk kompleks warna rosa yang sering disebut kelat rosasianin warna senyawa boron cyanon kurkumin kompleks. Sehingga kompleks warna tersebut yang dimanfaatkan untuk mengukur kadar boraks menggunakan alat Spektrofotomater UV-Vis, maka sampel yang akan diukur harus berupa larutan. 
Oleh karena itu sampel diabukan selama 5 jam untuk menguraikan senyawa-senyawa organik lain yang terdapat dalam sampel serta untuk memudahkan penentuan kadar boraks dalam sampel. Kemudian ditambahkan aquades panas didalam sampel yang telah diabukan bertujuan agar senyawa-sanyawa organik yang masih terdapat dalam sampel terurai, sehingga yang timbul adalah senyawa-senyawa anorganik (mineral) yang di tandai dengan terbentuknya abu berwarna putih. Adapun sampel yang dianalisis secara kuantitatif dengan menggunakan spektrofotometer UV-Vis adalah sampel yang positif mengandung boraks berdasarkan hasil pemeriksa kualitatif boraks bahwa dari 5 sampel siomay yang diperoleh di lingkungan Kota Palu tersebut 5 sampel menunjukkan kadar positif mengandung boraks dengan kadar yang terrendah yang ditemukan adalah $0.0213 \mathrm{mg} / \mathrm{g}$ dan kadar yang tertinggi yaitu $0.0314 \mathrm{mg} / \mathrm{g}$.

Menurut Nurkholidah, dkk. (2011) besarnya jumlah responden yang tidak mengetahui boraks dan bahayanya disebabkan karena faktor bahasa. Pongsavee (2009) menjelaskan pada konsentrasi boraks 0.15 ; 0.2 ; 0.3 ; dan $0.6 \mathrm{mg} / \mathrm{ml}$ limfosit menunjukkan proliferasi rendah dibandingkan dengan kelompok kontrol $0.1 \mathrm{mg} / \mathrm{ml}$ konsentrasi boraks. Konsentrasi boraks dari $0.15 ; 0.2 ; 0.3$; dan 0.6 $\mathrm{mg} / \mathrm{ml}$ memiliki efek genotoksik untuk kromosom manusia.

Berdasarkan data penelitian yang terdapat, Maka bisa dibandingkan bahwa kadar dalam siomay dengan menggunakan metode spektrofotometer UV-Vis yaitu kadar yang terendah adalah $0.0213 \mathrm{mg} / \mathrm{g}$ dan kadar yang tertinggi adalah $0.0314 \mathrm{mg} / \mathrm{g}$.

\section{Kesimpulan}

Siomay di lingkungan Kota Palu yang berlokasi didepan kampus Universitas Tadulako bahwa setiap sampel yang dilakukan pada penelitian ini tidak terdeteksi mengandung formalin sebagai bahan berbahaya bagi kesehatan. Sedangkan untuk penelitian boraks tidak terdeteksi mengandung boraks yang ditunjukkan dengan warna kertas kurkumin. Hasil penelitian yang telah dilakukan maka dapat di tarik kesimpulan bahwa dalam penentuan kadar boraks dalam siomay dengan menggunakan metode spktrofotometer UV-Vis yaitu nilai konsentrasi kadar dalam sampel siomay yang tertinggi yaitu $0.0314 \mathrm{mg} / \mathrm{g}$.

\section{Ucapan Terima Kasih}

Ucapan terimakasih disampaikan kepada Ratman selaku kepala laboratorium FKIP Universitas Tadulako.

\section{Referensi}

Alsuhendra, \& Ridawati. (2013). Bahan toksik dalam makanan. Bandung: PT Remaja Rosdakarya.

Efrilia, M. (2016). Identifikasi boraks dalam bakso di kelurahan bahagia Bekasi Utara Jawa Barat dengan metode analisa kualitatif. Jurnal Kesehatan, 1(1), 112-120.

Faradila. (2014). Identifikasi formalin pada bakso yang dijual pada beberapa tempat di kota Padang. Jurnal Kesehatan Andalas, 3(2), 156-158.

Habibah, T. (2013). Identifikasi penggunaan formalin pada ikan asin dan faktor perilaku penjual di pasar tradisional kota Semarang. Jurnal Kesehatan Masyarakat, 2(3), 1-10.

Hariyadi, S. (2013). Uji kandungan formalin pada ikan asin menggunakan sensor warna dengan bantuan FMR. Jurnal Eltek, 1(2), 55-70.

Lidya, S. (2014). Ekstraksi pigmen antosianin dari kulit buah naga merah (hyloceeus polyrhizus. Jurnal Teknik Kimia Universitas Sumatera Utara, 3(2), 25-29.

Litovitz, T. L., Schwartz, W. K., Oderda, G. M., \& Schmitz, B. F. (1998). Clinical manifertations of toxicity in a series of 784 boric acid ingestion. American Journal Emergency Medical, 6(3), 209-215.

Nash, T. (1953). The colorimetric estimation of formaldehyde by means of the hantzsch reaction. Biochemical Journal, 55(3), 416421.

Nurkholidah, Ilza, M., \& Jose, C. (2012). Analisis kandungan boraks pada jajanan bakso tusuk di sekolah dasar di Kecamatan Bangkinang Kabupaten Kampar. Jurnal Ilmu Lingkungan, 6(2), 134-145.

Pongsavee, M. (2009). Effect of borax on immune cell proliferation and sister chromatid exchange in human chromosomes. Journal of Occupational Medicine and Toxicology, 4(27), 1-6.

Purwanti, R., \& Widowati, D. (2003). Deteksi formalin dan penentuan total angka kuman pada tahu yang dijual di pasar Kartasura. Pharmacon Pharmaceutical Journal of Indonesia, 4(2), 96-99.

Sahara, E., \& Purawisastra, S. (2011). Penyerapan formalin oleh beberapa jenis bahan makanan serta penghilangannya melalui perendaman dalam air panas. Jurnal Penelitian Gizi dan Makanan, 34(1), 63-74.

Saputrayadi, A., Asmawati., Marianah., \& Suwati. (2018). Analisis kandungan boraks dan formalin pada beberapa pedagang bakso di kota Mataram. Jurnal Agrotek, 5(2), 107116.

Suntaka, D. F. A. L. (2014). Analisis kandungan formalin dan boraks pada bakso yang 
disajikan kios bakso permanen pada beberapa tempat di kota Bitung. Jurnal Fakultas Kesehatan Masyarakat, 4(1), 39-45.
Tumbel, M. (2010). Analisis kandungan boraks dalam mie basah yang beredar di kota Makassar. Jurnal Ilmiah Kimia dan Pendidikan Kimia, 11(1), 57-64. 